
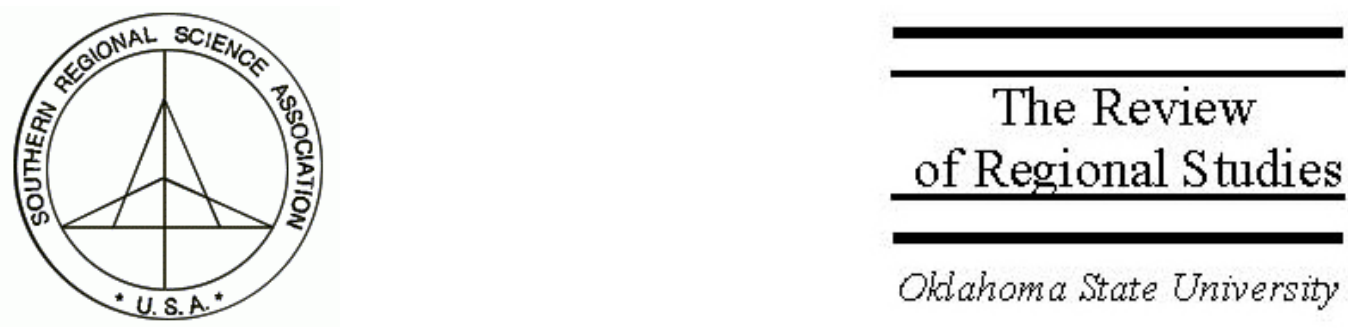

\title{
Natural Amenities and Rural Employment Growth: A Sector Analysis
}

\author{
Jason R. Henderson
}

Center for the Study of Rural America, Federal Reserve Bank of Kansas City, 925 Grand Boulevard, Kansas City, MO 64198, e-mail: jason.henderson@kc.frb.org

\section{Kendall McDaniel}

Chickasha Bank \& Trust Company, Chickasha, Oklahoma, e-mail:kmcdaniel@chickashabank.com

\begin{abstract}
Natural amenities have always been important to rural America. Places with high natural amenities enjoyed higher levels of employment, population, and income growth. However, the relationship between natural amenities and employment growth varies by industry and natural amenity type. Natural amenities do support the quality of life in rural areas. Yet, their impacts on service and retail sectors are more pronounced, with landscape amenities having greater impacts than weather amenities.
\end{abstract}

Keywords: Amenities; Rural; Manufacturing; Retail; Service; Employment growth

JEL classification: R11; O18

The views expressed are those of the authors and do not necessarily reflect the positions of the Federal Reserve Bank of Kansas City or the Federal Reserve System. 


\section{INTRODUCTION}

Natural resources are a primary source of economic growth in rural areas. American pioneers first forged west following the promises of rich farmland and California gold. Along the way, rural outposts grew into small towns and then large cities. Their growth depended on their ability to access natural resources and the water highways of the American west.

Many rural areas with natural resources continue to grow. ${ }^{1}$ The growth, however, is not being driven by resource extracting industries that have actually declined, but by the high quality of life associated with natural amenity areas. People visit and move to natural resource areas to enjoy the amenities they offer. Millions of people visit attractive rural areas rich in natural amenities to camp, ski, bike, hike, boat, or fish. Amenityrich areas are increasingly attractive to the creative class. Upon retirement, thousands of people move to high-amenity areas, highlighted by the annual winter migration of elderly populations to Florida, Texas, and other southern states. Today, rural areas with high levels of natural amenities experience faster population and employment growth than their counterparts (Henderson and McDaniel 1998; McGranahan 1999; McDaniel 2000; Deller et al. 2001).

But how do natural amenities impact the rural economy? Obviously, natural amenities support growth in tourism-based industries, industries serving retirees, and industries employing the creative class. This evidence suggests that rural areas could utilize natural amenities when forming an economic development strategy. Natural amenities, however, may not boost job rolls in all sectors of the rural economy. The impact of natural amenities on the manufacturing sector may be different than the impact on the retail and service sectors, because these industries have a different resource mix in their production functions. Determining the importance of natural amenities on employment growth in various rural sectors can help community leaders and policy makers use natural amenity in their rural development efforts.

This paper examines the impact of natural amenities on rural employment growth. First we analyze whether the relationship between natural amenities and employment growth varies across sector. Second we analyze whether the impacts of natural amenities on employment growth vary by the type of amenity - weather or landscape. To accomplish this objective, natural amenity measures are incorporated into a model of rural employment growth at the county level that controls for other factors - urbanization, localization of industries, market access, labor characteristics, transportation, and fiscal policies - that are also related to employment growth. Results should improve the understanding of the relationship between natural amenities and rural employment growth that currently exists.

\footnotetext{
${ }^{1}$ Rural is defined as all non-metro counties based on 1990 Office of Management and Budget classification. This definition is based on convenience of data availability at the county level.
} 
The paper is organized as follows. The first section describes the relationship between natural amenities and rural growth. The second section develops an empirical model to analyze the relationship between natural amenities and rural employment growth controlling for other growth factors. The third section describes the data used in the analysis. The fourth section presents and discusses the empirical results, and the last section provides a concluding summary.

\section{NATURAL AMENITIES AND THE RURAL ECONOMY}

In the spirit of McGranahan (1999), a natural amenity is a physical attribute of a location that enhances the location as a place of residence. By focusing on physical attributes, a natural amenity is not based upon the social or economic environment and purposely excludes man-made amenities such as historical buildings or casinos that may enhance the attractiveness of a physical amenity. The concentration of natural amenities in rural counties is measured with an index reflecting the environmental qualities most people prefer (McGranahan 1999). These measures are warm winter, winter sun, temperate summer, low summer humidity, topographic variation, and water area. According to the index, western regions of the U.S. had higher natural amenity levels along with coastal and southern regions (Figure 1). ${ }^{2}$

FIGURE 1

\section{Natural Amenities Index}

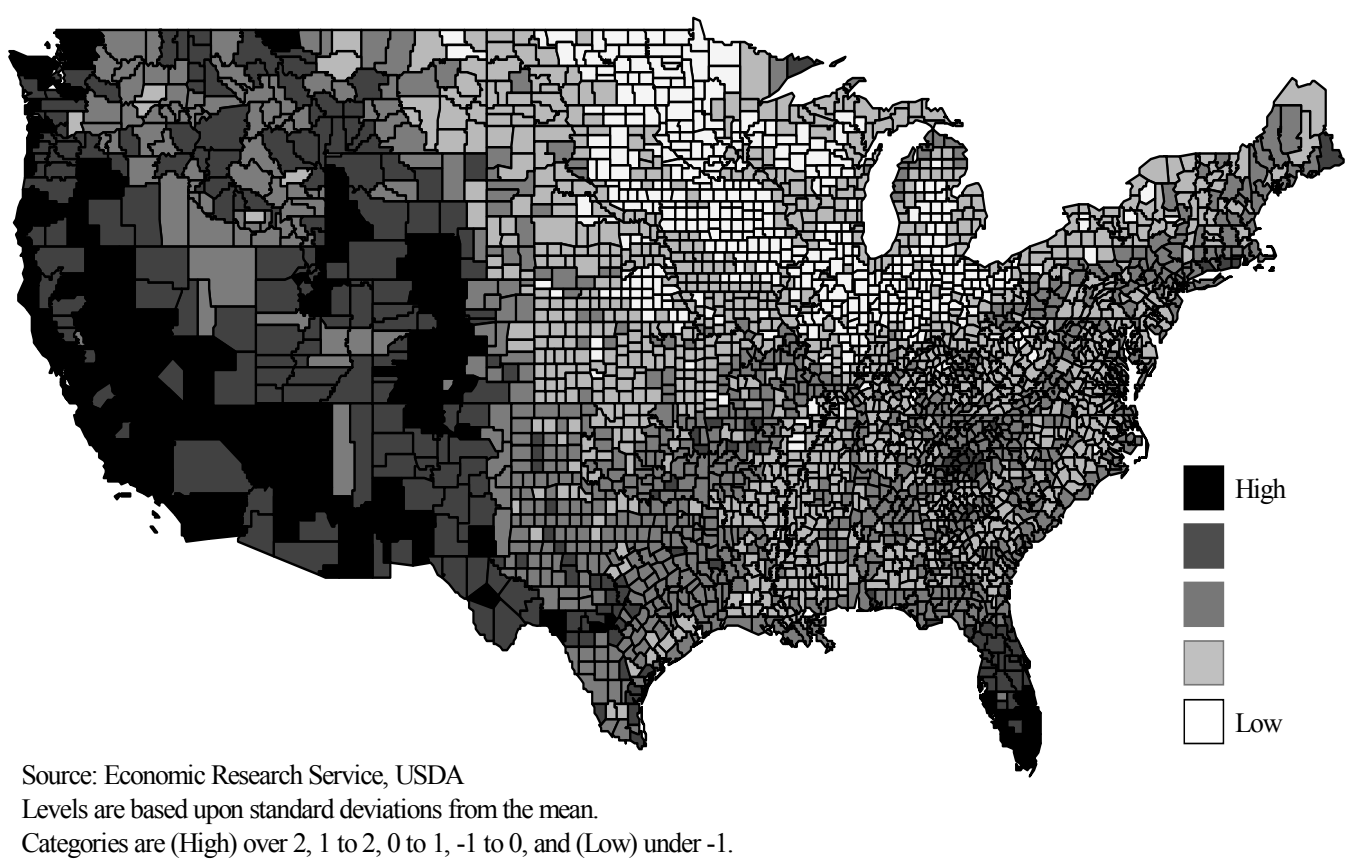

${ }^{2}$ The index equally weighted the six measures creating a potential bias towards western and southern states as individual measures could potentially impact rural areas differently. 


\subsection{Natural Amenities and Rural Growth}

Natural amenities impact rural economies in multiple ways. Initial research identified the impact of natural amenities on property values (Milon, Gressel, and Mulkey 1984; Bartik 1988; Blomquist, Berger, Hoehn 1988; Cheshire and Sheppard 1995; Lansford and Jones 1995; Ready, Berger, and Blomquist 1997; Benson et al. 1998). In general these studies find that the presence of natural amenities is associated with higher property values, as people prefer to live in scenic areas.

More recently, the impact of natural amenities on economic growth in rural areas has been investigated. Deller et al. (2001) show that rural areas with a higher concentration of natural amenities have a higher level of economic growth, measured by employment, population, and income. In addition, McDaniel (2000) finds that rural counties with higher levels of amenities experienced faster population growth during the 1990s. And, employment growth was also higher in rural counties with higher levels of natural amenities. In fact, rural counties possessing the highest level of natural amenities, according to the USDA amenity index, experienced 2.7 percent annual average growth in nonfarm employment from 1990 to 2000 compared to 1.4 percent in rural counties with the lowest level of natural amenities (Table 1).

Natural amenities support rural economies in many ways. Clearly natural amenities can support recreation and tourism growth. English, Marcouiller, and Cordell (2000) show that "recreational" nonmetro counties grew faster in terms of employment than other nonmetro counties in the 1980s. Henderson and McDaniel (1998) illustrate that rural areas with private establishments operating an outdoor sports or recreation camp, recreational vehicle parks, and campsites experienced higher levels of employment growth between 1990 and 1995 than rural areas without these establishments.

TABLE 1

Rural Employment Growth by Sector (Average Annual Growth 1990-2000)

\begin{tabular}{|c|c|c|c|c|c|}
\hline Amenity Rank & Total & Retail & Service & Government & Manufacturing \\
\hline 1 (Low) & 1.43 & 1.02 & 2.27 & 0.49 & 3.98 \\
\hline 2 & 1.52 & 1.76 & 2.41 & 1.06 & 1.22 \\
\hline 3 & 1.48 & 1.75 & 3.01 & 1.11 & 0.19 \\
\hline 4 & 1.70 & 2.12 & 3.21 & 1.49 & -0.66 \\
\hline 5 & 2.77 & 2.96 & 4.16 & 1.72 & 0.47 \\
\hline 6 & 3.02 & 2.81 & 4.30 & 2.52 & 0.30 \\
\hline 7 (High) & 2.67 & 2.30 & 3.86 & 1.90 & -0.31 \\
\hline Rural Total & 1.73 & 2.02 & 3.15 & 1.36 & 0.12 \\
\hline \\
\hline \multicolumn{6}{|c|}{$\begin{array}{c}\text { Amenity Rank }=\text { Deviations from the Mean } \\
\begin{array}{cc}2=-1 \text { to }-2 & 3=0 \text { to }-1 \\
6=2 \text { to } 3 & 7=\text { Over } 3\end{array}\end{array}$} \\
\hline
\end{tabular}

Calculations based on Bureau of Economic Analysis data.

Disclosure problems limit the availability of sector-level data for some rural counties. 
By supporting lifestyle amenities, natural amenities support higher levels of employment growth by attracting new residents, both workers and retirees. By providing a higher quality of life, natural amenity areas are attractive places to work and do business. In analyzing western states, Duffy-Deno (1998) suggests that regions near wilderness areas are attractive natural amenity locations. In fact, wilderness areas were found to be associated with higher levels of non-resource industry growth. Some of these places have high-quality labor at lower costs created by the willingness of the well-educated to trade income for a higher quality of life.

High amenity areas also serve as retirement destinations. Cromartie and Beale (1996) indicate that "retirement destination" rural counties often contain a high level of natural amenities. As the retirement population expands, the demand for local services, especially health care, increases. Population levels in "recreation" and "retirement" destination counties grew the fastest of all rural areas between 1990 and 1995 (Cromartie and Beale 1996). Beale and Johnson (1998) find that rural "recreational" areas account for 12 percent of the nonmetro counties but 15 percent of the nonmetro population. Population growth in these recreational counties exceeded those in other nonmetro areas as well as metro areas. As population growth and the demand for services expands in areas with high natural amenities, so do job opportunities.

\subsection{Sectoral Impacts of Natural Amenities}

Growth, however, can vary by sector. Duffy-Deno (1998) indicates that differences may arise between extractive and non-extractive resource industries. Differences may also be apparent within non-extractive resource industries due to variations in local markets or the industry's production function. By serving as recreation or retirement destinations, high amenity areas may have stronger local demand for personal service than other areas. Thus, the impact of amenities on the growth in local demand sectors - retail or service - may be stronger than other industries.

The mix of land, labor, and capital in the production function that varies across industry could also create variations in amenity impacts across industries. Because of higher property values, land costs are expected to be higher in amenity-rich locations. As a result, industries that are more land intensive, such as manufacturing, may be less attractive to high-amenity areas. Moreover, amenity-rich communities may be more restrictive and raise the costs for manufacturers industries that could potentially degrade amenity areas with emissions.

Differences may even arise from labor considerations. Rising U.S. incomes and higher standards of living are increasing the desire and capability of people to move to high-amenity places to boost their quality of life (Rappaport 2004). Some of these workers may be willing to receive a slightly lower income for a higher quality of life. The willingness to make the income and quality of life tradeoff is expected to be higher 
for the high-skilled, high-income individuals. ${ }^{3}$ Industries that employ a greater share of these individuals may be more attracted to high-amenity areas to help in recruitment and to lower explicit labor costs paid in wages.

Descriptive statistics shows that sector growth does vary by amenity level. Rural counties rich in natural amenities enjoyed faster employment growth in the service and government sectors than their counterparts. From 1990 to 2000, average annual employment growth in the retail, services, and government sectors rose 2.3, 3.9, and 1.9 percent, respectively, in rural counties with the highest level of natural amenities (Table 1). Rural counties with the lowest level of natural amenities in the 1990s experienced average annual employment growth in the retail, services, and government sectors of 1.0, 2.3 , and 0.5 percent, respectively. In contrast, manufacturing employment slowed noticeably in rural counties with higher levels of natural amenities. Manufacturing employment growth dropped 0.3 percent annually in counties with the highest level of natural amenities. However, manufacturing employment jumped 4.0 percent annually in counties with the lowest level of natural amenities.

While natural amenity impacts may vary by sector, the impacts could also vary by type of amenity. Industries may not be concerned about rugged landscapes, but they may prefer places of moderate weather to reduce winter heating and summer cooling costs. Quality of life perceptions probably vary by amenity type. Some people may prefer rugged terrain, while others flock to places with warm winter weather. The amenity value may differ by climate or landscape features.

Past literature and descriptive statistics indicate that natural amenities are a potential catalyst for rural employment growth. But other factors, such as urbanization, localization of industries, market access, labor characteristics, transportation, and fiscal policies, also contribute to rural employment growth (Barkley, Henry and Bao 1996; Bartik 1989; Fox and Murray 1990; O'Huallachain and Satterthwaite 1992; Henderson, Kuncoro, and Turner 1995; Henry and Drabenstott 1996; Ellison and Glaeser 1997; Deller et al. 2001). In order to isolate the importance of natural amenities to rural employment growth, an empirical model that controls for these factors is estimated.

\section{EMPIRICAL MODEL}

An empirical model is developed to analyze the impact of natural amenities on rural employment growth. The empirical model is built upon location theory following O'Huallachain and Satterthwaite (1992). Location theory states that firms search for locations that minimizes costs while meeting the firm's needs. Any aspect of the rural community that reduces firm costs leads to greater growth. By increasing the quality of life of a location, natural amenities reduce the costs necessary to attract residents,

\footnotetext{
${ }^{3}$ Rappaport indicates that rising incomes should increase the relative value of consumptive amenities, such as weather. Cragg and Kahn (1999) find that the implicit value of weather has risen over time.
} 
employees, and firms to an area. The model developed by O'Huallachain and Satterthwaite (1992) is presented in Equation 1.

$$
E_{L i}-E_{0 i}=a E_{0 i}^{\alpha} U_{i}^{\beta} \exp \left(c Z_{i}+\varepsilon_{i}\right)
$$

where $E_{1 i}$ is the employment for industry $i$ in the terminal period, $E_{0 i}$ is the employment for industry $i$ in the initial period, $U_{i}$ is the civilian labor force, and $Z_{i}$ is a vector of variables describing the geographic area.

Following O'Huallachain and Satterthwaite (1992), the log transformation of Equation 1 further modifies the model and leads to Equation 2.

$$
\operatorname{Ln}\left(E_{L i}-E_{0 i}\right)=L n a+\alpha \operatorname{Ln} E_{0 i}+\beta L n U_{i}+c Z_{i}+\varepsilon_{i}
$$

The empirical model provides an estimate of localization economies, urbanization effects, and other county characteristics. The impact of localization and urbanization economies on rural employment growth is measured by $\alpha$ and $\beta$, respectively. ${ }^{4}$ The influence of other county characteristics on rural employment growth is captured by $c$.

One advantage of this specification is that agglomeration factors, measured by employment and civilian labor force, are included in the model as interaction terms with other variables describing the geographic area. Moreover, Henry and Drabenstott (1996) indicate they use this specification because it avoids the problems associated with the size of the base year. However, a major drawback with this specification is that the dependent variable is undefined for regions with negative growth. Limiting analysis to those regions experiencing negative growth does pose the problem of sample selection bias. ${ }^{5}$

O'Huallachain and Satterthwaite (1992) use the above empirical model to analyze MSA high-tech employment growth between 1977 and 1984. Their analysis measured the impact of localization and urbanization economics on high-tech industry growth. In their model, they included a climate index variable to measure the quality of life in the MSA and the reduced costs associated with the attraction of firms and individuals. Their climate index included temperature extremes, duration of hot and cold days, and annual heating-degree days. In general, the climate measure was not found to significantly impact MSA employment growth in the various high-tech industries analyzed.

\footnotetext{
${ }^{4}$ McDonald (1989) interprets $\alpha$ greater than 1 to mean that increases in $E_{0 i}$ lead to faster growth rates in the rural industry. $\alpha$ greater than 0 but less than 1 that increases in $E_{0 i}$ lead to faster absolute growth, but slower growth rates, while $\alpha$ less than 0 mean that increases in $E_{0 i}$ lead to declines in industry growth. A positive $\beta$ indicates that a larger labor force encourages growth in the industry, while a negative $\beta$ indicates a larger labor force hinders industry growth.

${ }^{5}$ Henry and Drabenstott (1996) state that the bias is not likely to be large if one assumes that the factors associated with employment growth are different than the factor and forces associated with employment decline.
} 
Henry and Drabenstott (1996) implemented a version of the empirical model to analyze growth in rural hinterlands of the Bureau of Census Component Economic Areas. They did not include a measure of natural amenities in their model, but they state that anecdotal evidence points to natural amenities as one driver of employment growth in rural hinterlands.

This paper extends the literature by applying the model to sector-level employment growth in rural counties. ${ }^{6}$ Incorporating natural amenity indexes into the model provides additional insight into the impact of natural amenities on rural employment growth. The empirical model allows for the isolation of the impact of natural amenities on employment growth controlling for other factors. Applying the empirical model to sector-level employment models can explain the impact of natural amenities on different sectors of the rural economy. It is expected that natural amenities will have the largest impacts on rural service and retail growth.

\section{DATA}

The empirical model is first employed to analyze rural counties experiencing total employment growth between 1990 and 1997. ${ }^{7}$ County-level employment data is obtained from the Regional Economic Information System maintained by the Bureau of Economic Analysis. The model is then applied to rural counties experiencing average annual employment growth in the manufacturing, service, and retail sectors. Disclosure problems in various sectors of the rural economy reduced the number of counties to 2,254 overall. Only 2,138,2,121, and 2,237 rural counties can be analyzed for manufacturing, service, and retail, respectively, due to disclosure problems.

Various county characteristics that impact firm costs and thus encourage business activity and employment growth are included as independent variables in the empirical model. Independent variables include agglomeration economies, market access, infrastructure, labor characteristics, and fiscal policies in addition to the natural amenity index.

\subsection{Natural Amenities}

Higher levels of natural amenities should lead to faster employment growth in rural areas as natural amenities attract workers, firms, retirees, and tourists. The USDA index briefly described previously is used to measure natural amenity levels. ${ }^{8}$ The index is

\footnotetext{
${ }^{6}$ Deller et al. (2001) and Duffy-Deno (1998) explored the role of natural amenities and wilderness on employment and income growth in a Carlino and Mills model.

${ }^{7} 1997$ is used as the terminal year because rural (nonmetro) employment growth outpaced metro employment growth until 1998. After this time, rural growth trailed metro growth. Additional analysis was performed using 2000 as the terminal year to check for robustness. The model results were consistent, and the 1997 data was used because of fewer disclosure problems with 1997 data.

${ }^{8}$ A more complete description of the natural amenity measures is available in McGranahan (1999).
} 
derived from six individual measures of natural amenities that cover two broad types weather and landscape amenities (McGranahan 1999).

Two measures of winter weather are included in the amenity index. The average January temperature between 1941 and 1970 is included. Warm winters are attractive to retirees and tourists. Rural areas with warm winter temperatures are expected to have higher employment growth, ceteris paribus. The number of hours of January sunlight between 1941 and 1970 is another measure of winter amenities. Sunny skies are a positive amenity attribute for most people. Areas with more winter sun are expected to have higher employment growth.

Two measures of summer weather are also included in the index. The average July temperature between 1941 and 1970 is included. A low measure indicates areas with a temperate summer, an attractive natural amenity. Regions with temperate summers are expected to have higher employment growth. The average July relative humidity level between 1941 and 1970 is a measure of summer discomfort. Regions with low summer humidity are expected to have higher employment growth.

A composite weather index, WEATHER, is developed by summing the standardized values of the winter and summer weather measures. A higher weather amenity index value indicates places with temperate summers and warmer winters. A positive relationship between WEATHER and employment growth is expected.

The natural amenity index is also composed of two landscape measures: topographic variation and water area. Coastal settings, lake areas, and mountain ranges are appealing natural amenities for most people. Large bodies of water provide recreational activities for tourists and residents. Natural amenities are more appealing in locations with more topographic variation. The percentage of the total acreage in the county covered by water is included in the index. The index also includes a scale measure of topographic variation. The measure is based upon 21 topographic categories ranging from flat plains to high mountains, where flat plains were given a value of 1 and high mountains a value of 21. Areas with more landscape amenities are expected to have higher employment growth as people visit and move to these areas.

A composite landscape index, LANDSCAPE, is developed by summing the standardized values of the topography and water measures, each calculated by USDA. A higher landscape amenity index value indicates places with increased topographic variation and more water. A positive relationship between LANDSCAPE and employment growth is expected.

\subsection{Agglomeration}

The presence of agglomeration economies in the rural community lowers the average costs of production and can be grouped into two broad categories (Henderson, Kuncoro, and Turner 1995). First, urbanization economies reduce firms' average cost of 
production by providing the advantages of improved infrastructure, a wide array of personal and business services, and larger labor markets (Barkley, Henry, and Bao 1996; Henry, Barkley, and Bao 1997; O’Huallachain and Satterthwaite 1992). Higher labor force levels should encourage higher levels of rural employment growth. The labor force in the rural county in 1990, $L A B O R$, measures the presence of urbanization economies (O'Huallachain and Satterthwaite 1992; Henry and Drabenstott 1996).

Second, localization economies support economic growth by reducing the cost of information to firms (Henderson, Kuncoro, and Turner 1995; Ellison and Glaeser 1997; O'Huallachain and Satterthwaite 1992). A cluster of firms improves the sharing of knowledge among related firms. Given today's movement toward a more knowledgebased economy, the cost savings associated with localization economies should enhance employment growth in rural areas. ${ }^{9}$ A rural community with a cluster of related firms indicates the presence of factors that currently support firm success. The level of sector employment in 1990, SECTOR, is used to measure localization economies. ${ }^{10}$

\subsection{Labor}

Local labor characteristics influence the average cost of production for firms. Lower labor costs lead directly to lower production costs, ceteris paribus. Lower wages or income levels should encourage rural employment growth. WAGES are measured as the annual non-farm income per person in the rural county in 1990.

The quality of the labor force also influences the average cost of production for firms. A higher skilled labor force is expected to be more efficient and reduce the costs of production. Thus, locations with higher quality labor should lead to higher rural employment growth. The percentage of the county's population that is 25 years or older with a high school diploma in 1990, GRADRATE, measures the quality of labor force in the area.

\subsection{Transportation Infrastructure}

Interstate access is another community characteristic that lowers the average cost of production. Access to a national road system allows firms to distribute finished products to customers or acquire inputs from suppliers in distant markets at a lower cost. Therefore, a positive relationship is expected between interstate mileage and rural employment growth. The density of rural interstate mileage in the county in 1992, INTSTATE, is included in the empirical model to measure interstate access.

\footnotetext{
${ }^{9}$ Henderson and Abraham (2004) find that concentrations of knowledge occupations are higher in rural counties with both urbanization and localization agglomeration economies.

${ }^{10}$ This variable will change for each sector model that is estimated, accounting for the multiple reported descriptive statistics in Appendix A.
} 


\subsection{Public Expenditures}

Higher levels of local government expenditures should reduce a firm's average costs of production. Local provision of infrastructure such as water and waste removal systems can improve the productivity of firms. Public provision also leads to sharing of costs among firms and residents. Yet financing the provision of local expenditures raises the costs of production for firms. The amount of local government expenditures per capita in 1987 in thousands, EXPEND, measures the benefits derived from the provision of government services and is expected to be positively related to employment growth. The cost of government is measured by PROPTAX, property taxes per capita in 1987 in thousands. PROPTAX is expected to be negatively related to employment growth.

\subsection{Regional Variables}

Regional dummy variables were included for the Midwest, South, and West to account for regional characteristics that shape the cost of business activities that are not included in the empirical model. The regions are combinations of the Bureau of Census regions. ${ }^{11}$

\section{EMPIRICAL RESULTS}

The empirical model provides a good fit for rural employment growth overall and at the sector level. The model in Equation 2 is estimated with a Tobit model. Since the dependent variable is the log of the difference between employment levels in 1997 and 1990, counties that experienced negative employment growth are left censored at zero. The dummy variable CENSOR is included in the regression to identify counties that experienced negative growth. ${ }^{12}$

When possible, independent variables are matched to the beginning of the period to identify initial conditions. Estimations are conducted on total employment growth and employment growth in the manufacturing, service, and retail sectors. The results are presented in Table 2. The pseudo $\mathrm{R}^{2}$ statistic for all models is approximately $0.45 .{ }^{13}$ Multicollinearity does not appear to be a significant problem since variance factors are

11 MIDWEST includes the states of Illinois, Indiana, Iowa, Kansas, Michigan, Minnesota, Missouri, Nebraska, North Dakota, Ohio, South Dakota, and Wisconsin. SOUTH includes the states of Alabama, Arkansas, Florida, Georgia, Kentucky, Louisiana, Mississippi, North Carolina, South Carolina, Tennessee, Virginia, West Virginia, New Mexico, Oklahoma, and Texas. WEST includes the states of California, Colorado, Idaho, Montana, Nevada, Oregon, Utah, Washington, and Wyoming.

${ }^{12}$ Initial analysis included only those counties with positive growth. Results from these regressions were consistent with the results from analysis that included counties with negative growth and the variable CENSOR.

${ }^{13}$ Pseudo $\mathrm{R}^{2}$ is the McKelvey/Zavoina measure $\left(\mathrm{R}_{\mathrm{MZ} 1}^{2}\right)$ recommended by Veall and Zimmerman (1994). 
slightly higher than 2 , condition indexes were roughly 30 , and coefficients met a priori expectations. $^{14}$

In the total employment growth model, all variables except EXPEND are significant at the 0.05 level. In the manufacturing growth model, SECTOR, EXPEND, and MIDWEST are significant at the 0.01 level and $L A B O R$ was significant at the 0.01 level. ${ }^{15}$ All variables expect PROPTAX and EXPEND are significant at the 0.05 level in the service model, and INTSTATE is significant at the 0.10 level. All of the variables except EXPEND were significant in the retail growth models at the 0.05 level.

Rural employment growth was higher in areas with more natural amenities. Weather and landscape amenities are associated with rural employment growth, as expected. ${ }^{16}$ Both WEATHER and LANDSCAPE were positive and highly significant in the total rural

TABLE 2

Marginal Effects of Tobit Model with Amenity Variables

\begin{tabular}{|c|c|c|c|c|c|c|c|c|}
\hline & \multicolumn{2}{|c|}{$\begin{array}{l}\text { Total Nonfarm } \\
\text { (Model 1) }\end{array}$} & \multicolumn{2}{|c|}{$\begin{array}{l}\text { Manufacturing } \\
\text { (Model 2) }\end{array}$} & \multicolumn{2}{|c|}{$\begin{array}{c}\text { Service } \\
\text { (Model 3) }\end{array}$} & \multicolumn{2}{|c|}{$\begin{array}{c}\text { Retail } \\
\text { (Model 4) }\end{array}$} \\
\hline & Coefficient & $\begin{array}{l}\text { St. } \\
\text { Error }\end{array}$ & Coefficient & $\begin{array}{l}\text { St. } \\
\text { Error }\end{array}$ & Coefficient & $\begin{array}{l}\text { St. } \\
\text { Error }\end{array}$ & Coefficient & $\begin{array}{l}\text { St. } \\
\text { Error }\end{array}$ \\
\hline \multicolumn{9}{|c|}{ Natural Amenities } \\
\hline WEATHER & $0.057^{*}$ & 0.014 & 0.022 & 0.020 & 002 & 0.014 & $0.033 \#$ & 0.014 \\
\hline & $0.109 *$ & 0.016 & -0.029 & 0.022 & $.110^{*}$ & 0.016 & $0.093 *$ & 0.016 \\
\hline \multicolumn{9}{|c|}{ Control Variables } \\
\hline $\operatorname{Ln}(L A B O R)$ & $0.757 *$ & 0.099 & 0 & 0.055 & $4^{*}$ & 0.0 & $55^{*}$ & 0.075 \\
\hline & $0.262 *$ & 0.088 & 0.2 & 0.031 & $8^{*}$ & 0.0 & $10^{*}$ & 0.060 \\
\hline$G R A$ & $1.261 *$ & 0.288 & 0.050 & 0.395 & $782 *$ & 0.291 & $1.749 *$ & 0.280 \\
\hline WAGE & $-0.029 *$ & 0.006 & 0.00 & 0.008 & $-0.013 *$ & 0.006 & $-0.017 *$ & 0.006 \\
\hline & $1.849 *$ & 0.699 & 1.107 & 0.882 & $1.788 \#$ & 0.960 & $2.111 *$ & 0.675 \\
\hline$P R O$ & $-0.166^{*}$ & 0.083 & -0.140 & 0.123 & -0.136 & 0.087 & $-0.192 *$ & 0.079 \\
\hline EXPEND & 000 & 0.046 & $-0.244 *$ & 0.066 & 0.000 & 0.048 & -0.064 & 0.044 \\
\hline MIDWEST & $0 *$ & 0.096 & * & 0.132 & $519 *$ & 0.094 & $0.614 *$ & 0.092 \\
\hline & & 0. & & 0 & 5* & 0.1 & 76* & 0.101 \\
\hline & & & & 01 & $1 *$ & 0.112 & $0.884 *$ & 0.108 \\
\hline C & -6.07 & 0.0 & -5.0 & 0.058 & $-4.774 *$ & 0.096 & $-4.550 *$ & 0.086 \\
\hline CON & $-5.284 *$ & 0.479 & $1.179 *$ & 0.518 & $-4.486^{*}$ & 0.475 & $-5.361 *$ & 0.516 \\
\hline Pseud & 0.455 & & 0.504 & & 0.448 & & 0.446 & \\
\hline Observations & 2,254 & & 2,138 & & 2,121 & & 2,237 & \\
\hline
\end{tabular}

*Significant at the 0.05 level. \# Significant at the 0.10 level. Two-tailed test.

Pseudo $\mathrm{R}^{2}$ is the McKelvey/Zavoina measure (R2MZ1) recommended by Veall and Zimmerman (1994).

\footnotetext{
${ }^{14}$ Only EXPEND in the manufacturing model failed to have the expected sign.

${ }^{15}$ Additional regressions found the number of interstate miles instead of interstate density to be significant in the manufacturing model.

${ }^{16}$ The amenity variables only measure the partial impacts of amenities on growth. The amenity variables do not measure the impacts associated with the willingness of people to trade a lower income for a higher quality of life associated with amenities.
} 
nonfarm employment growth model (Model 1). Areas with warm winters and temperate summers had higher levels of employment growth in the 1990s. Rural locations with warmer winters and more hours of winter sun experienced higher levels of employment growth. Communities with low levels of summer discomfort, as measured by SUMTEMP and SUMHUM, had higher levels of employment growth. Rural employment growth was also higher in rural areas with lake and mountain access, measured by WATER and TOPOGVAR, respectively. The results confirm earlier findings that natural amenities do support rural employment growth.

More importantly, the impact of natural amenities appears to vary across sectors. Manufacturing employment growth was not related to either the weather or the landscape amenity index (Model 2). ${ }^{17}$ In fact, although insignificant, the landscape variable was negatively associated with manufacturing growth. ${ }^{18}$ Moreover, WAGE was not found to be significantly related to manufacturing employment growth, mitigating the impact of amenities on growth through the trading of less income for scenic amenities.

In contrast, a positive relationship was found between the amenity indexes and service and retail employment growth. However, the relationship did vary by the type of amenity. The composite weather amenity index was only significant in the retail model (Model 4). Yet the composite landscape amenity index was related to employment growth in the service and retail sectors. Employment growth in the service and retail sectors was higher in rural areas with larger bodies of water and greater topographic variation.

The amenity variables only measure the partial impacts of amenities on growth. Some of the other included variables, such as wage rates and regional dummy variables, may be capturing some of the amenity effects. For example, people may be willing to trade a lower income for a higher quality of life associated with amenities. Additional analysis was conducted to analyze the sensitivity of the amenity variables to the specification of the model. For example, when wage rates were excluded from the model, the significance of the amenity variables did not vary. Moreover, the marginal effects for the amenity variables were not significantly different from the marginal effects presented in Table 2 .

Model specifications that excluded the regional dummy variables had mixed results. In the service and retail models, the weather amenity variable remained positive and became significant at the 0.05 level. The landscape amenity variable remained positive and significant. In the manufacturing model, however, the weather variable remained positive and insignificant, but the landscape variable remained negative and became significant at the 0.10 level.

\footnotetext{
${ }^{17}$ Additional regression analysis substituted the WEATHER and LANDSCAPE variables with the natural amenity index that included both weather and landscape attributes. The index had a positive and significant relationship with total nonfarm, service, and retail employment growth.

${ }^{18}$ LANDSCAPE was negative and significant at the 0.15 level.
} 


\section{CONCLUSION}

Natural resources have been and continue to be a key to economic growth in rural areas. Natural amenities improve rural quality of life and boost the attractiveness of rural places to workers, recreationers, retirees, and businesses. Indeed, results of this paper support the hypothesis that natural amenities, as measured by the USDA index, enhance rural employment growth. Rural areas with warm winters, temperate summers, topographic variation, and water had higher levels of employment growth in the 1990s. These results suggest that exploiting the presence of natural amenities could be an effective rural economic development strategy.

However, strategies focusing on the development of natural amenities may not boost all rural industries. The results show that natural amenities impact the service, retail, and manufacturing sectors in different ways. Employment growth in the service and retail sectors was higher in rural areas with higher natural amenity areas. By being attractive locations for tourists and retirees, rural places with higher levels of natural amenities appear to have stronger demand for local service-producing activities, especially from the retail sector.

In contrast, rural manufacturing job growth was not significantly related to weather or landscape amenities. While natural amenities may be attractive to people to live, work, or recreate, the people may not be boosting the demand for manufactured goods in the region. As a result, manufacturers may view high amenity areas as locations with weak local demand and high costs associated with higher property values. Moreover, the value of amenities may move local authorities to be more restrictive in new factory locations or expansions and more stringent enforcement of factory emissions to limit the degradation of natural amenities in the local area. Given the mixed impacts at the sector level, rural communities focusing their economic development efforts on natural amenities need to recognize that these efforts may not boost job growth in all sectors.

The impact of natural amenities on rural employment growth also varies by the type of amenity. Landscape amenities - topographic variation and water area - are related to employment growth in all non-manufacturing sectors. Weather related amenities - temperate summers and warm winters - have a mixed relationship with rural nonmanufacturing sectors. Weather amenities were only found to be related to retail employment growth.

By boosting rural quality of life, natural amenities appear to support rural service and retail employment growth. However, some of the service and retail industries such as recreation industries particularly attracted to natural amenity areas tend to offer lowskilled, low wage job opportunities. While a natural amenity development strategy may produce jobs, these jobs many not be high paying jobs. However, natural amenities are increasingly appealing to high-skilled, high-income populations and may be a driver in high-skilled industry and high-wage job growth. Future work will need to explore the relationship between natural amenities and high-skilled, high-wage activities. Taken 
together, natural amenities will continue to be a factor in rural development strategies, and more analysis is needed to determine whether they are particularly effective in forging high-skilled activity in rural America.

\section{REFERENCES}

Barkley, D.L., M. Henry, and S. Bao, 1996. "Identifying 'Spread' versus 'Backwash' Effects in Regional Economic Areas: A Density Functions Approach," Land Economics 72(3), 336-357.

Bartik, T., 1988. "Measuring the Benefits of Amenity Improvements in Hedonic Price Models," Land Economics 64(2), 72-83.

, 1989. "Small Business Start-Ups in the United States: Estimates of the Effects of Characteristics of States," Southern Economic Journal 55, 1004-1018.

Beale, C.L. and K.M. Johnson, 1998. "The Identification of Recreational Counties in Nonmetropolitan Areas of the USA," Pop. Res. Policy Rev. 17(1), 37-53.

Benson, E.D., J.L. Hansen, A.L. Schwartz, Jr., G.T. Smersh, 1998. "Pricing Residential Amenities: The Value of a View," Journal of Real Estate Finance and Economics 16(1), 55-73.

Blomquist, G., M. Berger, and J. Hoehn, 1988. "New Estimates of Quality of Life in Urban Areas," American Economic Review 78(1), 89-107.

Cheshire, P. and S. Sheppard, 1995. "On the Price of Land and the Value of Amenities," Economica 62(246), 247-267.

Cromartie, J. and C. Beale, 1996. "Rural Population Rebounds in the 1990s," Agricultural Outlook. Economic Research Service, U.S. Department of Agriculture. November, 18-21.

Cragg, M.I. and M. Kahn, 1999. "Climate Consumption and Climate Pricing from 1940 to 1990," Regional Science and Urban Economics 29(4), 529-539.

Deller, S., T. Tsai, D.W. Marcouiller, and D. English, 2001. "The Role of Amenities and Quality of Life in Rural Economic Growth," American Journal of Agricultural Economics 83(2), 352-365.

Duffy-Deno, K.T., 1998. "The Effect of Federal Wilderness on County Growth in the Intermountain Western United States," Journal of Regional Science February 38(1), 109-136.

Ellison, G. and E. Glaeser, 1997. "Geographic Concentration in U.S. Manufacturing Industries: A Dartboard Approach," Review of Economics and Statistics 105(5), 889927.

English, D.B.K., D.W. Marcouiller, and H.K. Cordell, 2000. "Linking Local Amenities with Rural Tourism Incidence: Estimates and Effects," Society of Natural Resources 13(3), 185-202.

Fox, W.F. and M.N. Murray, 1990. "Local Public Policies and Interregional Business Development," Southern Economics Journal 57, 413-427.

Henderson, J. and K. McDaniel, 1998. "Do Scenic Amenities Foster Economic Growth in Rural Areas?" Federal Reserve Bank of Kansas City, Regional Economic Digest, First Quarter, 11-17. 
Henderson, J. and B. Abraham, 2004. "Can Rural America Support a Knowledge Economy?" Federal Reserve Bank of Kansas City Economic Review, Third Quarter, 89(3), 71-95.

Henderson, V., A. Kuncoro, and M. Turner, 1995. "Industrial Development in Cities," Review of Economics and Statistics 103(5), 1067-1085.

Henry, M., D.L. Barkley, and S. Bao, 1997. "The Hinterland's Stake in Metropolitan Growth: Evidence from Selected Southern Regions," Journal of Regional Science 37(3), 479-501.

Henry, M. and M. Drabenstott, 1996. "A New Micro View of the U.S. Rural Economy," Federal Reserve Bank of Kansas City, Economic Review, Second Quarter, 53-70.

Lansford, N. and L. Jones, 1995. "Marginal Price of Lake Recreation and Aesthetics: An Hedonic Approach," Journal of Agricultural and Applied Economics 27(1), 212223.

McDaniel, K., 2000. “Can Scenic Amenities Offer Rural Gain Without Pain?” Center for the Study of Rural America, Federal Reserve Bank of Kansas City, The Main Street Economist, September.

McDonald, J., 1989. "On the Estimation of Localization Economies," Economic Letters $3,275-277$.

McGranahan, D., 1999. "Natural Amenities Drive Rural Population Change," Agricultural Economic Report No. 781, Food and Rural Economics Division, Economic Research Service, U.S. Department of Agriculture.

Milon, J.W., J. Gressel, and D. Mulkey, 1984. "Hedonic Amenity Valuation and Functional Form Specification," Land Economics 60(4), 378-387.

O'Huallachain, B. and M. Satterthwaite, 1992. "Sectoral Growth Patterns at the Metropolitan Level: An Evaluation of Economic Development Initiatives," Journal of Urban Economics 26(1), 19-32.

Rappaport, J. 2004. "Moving to Nice Weather," RWP 03-07, Federal Reserve Bank of Kansas City.

Ready, R., M. Berger, and G. Blomquist, 1997. "Measuring Amenity Benefits from Farmland: Hedonic Pricing vs. Contingent Valuation," Growth and Change 28(4), 438-458.

Veall, M.R. and K.F. Zimmerman, 1994. "Goodness of Fit Measures in the Tobit Model," Oxford Bulletin of Economics and Statistics 56(4), 485-499. 
APPENDIX

\begin{tabular}{|c|c|c|c|c|c|c|c|}
\hline \multicolumn{8}{|c|}{ Descriptive Statistics } \\
\hline & Mean & Std. Error & Median & Mode & Minimum & Maximum & Count \\
\hline \multicolumn{8}{|l|}{ Dependent Variables } \\
\hline Total & 6.223 & 0.047 & 6.736 & 0.000 & 0.000 & 9.978 & 2,254 \\
\hline Manufacturing & 3.013 & 0.060 & 3.584 & 0.000 & 0.000 & 8.623 & 2,138 \\
\hline Service & 5.332 & 0.042 & 5.666 & 0.000 & 0.000 & 9.476 & 2,121 \\
\hline Retail & 4.874 & 0.040 & 5.226 & 0.000 & 0.000 & 8.510 & 2,237 \\
\hline \multicolumn{8}{|c|}{ Independent Variables } \\
\hline WEATHER & 0.028 & 0.040 & -0.284 & -0.859 & -3.769 & 7.965 & 2,254 \\
\hline LANDSCAPE & -0.061 & 0.027 & -0.0119 & -3.394 & -3.394 & 3.804 & \\
\hline $\operatorname{Ln}(L A B O R)$ & 11.126 & 0.021 & 11.174 & 10.467 & 7.650 & 13.843 & 2,254 \\
\hline \multicolumn{8}{|l|}{$\operatorname{Ln}(S E C T O R)$} \\
\hline Total & 8.678 & 0.023 & 8.699 & 7.705 & 4.477 & 11.347 & 2,254 \\
\hline Manufacturing & 6.668 & 0.034 & 6.906 & 4.007 & 0.000 & 10.226 & 2,138 \\
\hline Service & 7.182 & 0.025 & 7.179 & 6.877 & 3.091 & 10.382 & 2,121 \\
\hline Retail & 6.887 & 0.024 & 6.941 & 5.905 & 2.708 & 9.718 & 2,237 \\
\hline GRADRATE & 0.676 & 0.002 & 0.691 & 0.578 & 0.316 & 0.955 & 2,254 \\
\hline WAGE & 15.496 & 0.073 & 15.055 & 12.750 & 4.692 & 35.905 & 2,254 \\
\hline INTSTATE & 0.011 & 0.001 & 0.000 & 0.000 & 0.000 & 0.834 & 2,254 \\
\hline PROPTAX & 0.433 & 0.008 & 0.331 & 0.206 & 0.020 & 5.204 & 2,254 \\
\hline EXPEND & 1.375 & 0.012 & 1.250 & 1.120 & 0.184 & 5.775 & 2,254 \\
\hline
\end{tabular}

